\title{
THE IRREDEEMABLE DEBT: \\ ON THE ENGLISH TRANSLATION OF LACAN'S FIRST TWO PUBLIC SEMINARS
}

\author{
Dany Nobus, London, $U K^{1}$
}

DANY NOBUS is Professor of Psychoanalytic Psychology at Brunel University London, and the Chair of the Freud Museum London. He is the author of numerous books and papers on the history, theory and practice of psychoanalysis, most recently The Law of Desire: On Lacan's 'Kant with Sade' (Palgrave, 2017). Address for correspondence: Brunel University London, Kingston Lane, Uxbridge UB8 3PH, UK. [dany.nobus@brunel.ac.uk]

\section{Introduction}

In this essay, I want to reconstruct the troubled history of the first robust attempt at making the work of the French psychoanalyst Jacques Lacan (1901-1981) newly available to Englishspeaking readers after his death. In the almost forty years that have passed, this story has never been told, and it is in many ways revealing for the way in which the transmission and dissemination of Lacan's ideas took a new turn following the dissolution of his École freudienne de Paris in January 1980 (Lacan, 1980) and his fatal spell of ill-health the year after. The initiative was the brainchild of John Forrester (1949-2015), and it coincided with an unprecedented, large-scale proposal to generate English translations of some of Lacan's most important writings that had not been included in a previously published selection (Lacan, 1977), of some of his seminars, and of the best books published by French psychoanalysts working in the Lacanian tradition. If the project only crystallised, a great many years after it

\footnotetext{
${ }^{1}$ This essay would not have been completed without the help and encouragement of the following people: Parveen Adams, Lisa Appignanesi, Bernard Burgoyne, Matt ffytche, Bruce Fink, Russell Grigg, Brett Kahr, Darian Leader, Andreas Mayer, Ian Parker, Barry O’Donnell, Donna Redmond, Martin Thom, Sylvana Tomaselli and Ivan Ward. I would also like to thank Nigel Cochrane, Assistant Director (Academic and Research Services) of the Albert Sloman Library at the University of Essex, for his assistance in providing access to the John Forrester papers. Finally, I would like to extend a posthumous word of thanks to the late great John Forrester himself, for generously sharing his recollections of the translation-project, and many other Lacanian adventures. A preliminary version of this essay was prepared for the international colloquium 'Penser et écrire l'histoire de la psychanalyse et des sciences humaines: autour de l'œuvre de John Forrester', organised by Andreas Mayer at the École des Hautes Études en Sciences Sociales in Paris on 23 May 2016.
} 
was initiated, in the English translation of Lacan's Seminar I and Seminar II, I will demonstrate that this was by no means the fault of the tenacious scholar who dedicated his time and efforts to it. In addition, I will outline how this new major translation project did not run aground on questions of translation per se, but rather on unresolvable disagreements between Forrester, publishing houses, and Lacan’s designated intellectual legatee Jacques-Alain Miller as to how Lacan's works should be framed and presented to an English-speaking readership. In order to keep the essay's focus narrow and tight, I shall refrain from commenting on the style and accuracy of the translations themselves. A detailed critical analysis of the English translations of Lacan's Seminar I and II would no doubt warrant a lengthy separate study. However, it is worth noting that over the years some of the most respected Lacan-scholars and translators have found little to fault in these volumes (Macey, 1989; Turkle, 1989; Fink, 1990; Grigg, 1999), which cannot be said for Alan Sheridan’s 1977 translations of Lacan’s Seminar XI and the selected Écrits (Lacan, 1977[1973]; 1977), nor for some of the other Lacan-texts in English that appeared afterwards, including a pivotal collection of texts dealing with feminine sexuality (Mitchell and Rose, 1982; Fink, 2004; 2014).

To enable the reader to put Forrester’s initiative into its historical context, I shall briefly recapitulate, here, the key milestones of Lacan's reception in the English-speaking world during his lifetime. The first thing to note, in this respect, is that Lacan never seems to have been terribly interested in brokering English translations of his work, anglophile and selfpromoting though he was, unless we are to assume, of course, that the slowness of Lacan's English reception is merely indicative of a persistent lack of international enthusiasm for his contributions, not in the least amongst anglophone psychoanalysts. The first of his papers to be translated into English was 'L’instance de la lettre dans l'inconscient' (1957). It appeared in October 1966, when Lacan was sixty-five years old, about a month before a prodigious collection of his writings landed in the French bookshops as a thumping doorstop plainly 
inscribed Écrits (1966). The essay was translated and introduced, under the banner of psychiatry rather than that of psychoanalysis, by Jan Miel (1930-2015) - a Professor of Romance Languages at Wesleyan University - for a special issue of Yale French Studies on structuralism (Lacan 1966[1957]; Miel, 1966). At the end, the journal also included an annotated partial bibliography of Lacan’s writings by Anthony Wilden, a young British émigré who was completing the first doctoral dissertation on Lacan at Johns Hopkins University (Wilden, 1966). At that time, Lacan had published a mere two pieces in English. The first was the transcript of a lecture on the ego he had presented to The British Psycho-Analytical Society in May 1951 (Lacan, 1953), which did not receive any attention in the English-speaking world at all, save a vitriolic precis of its contents by the American psychoanalyst Henry Harper Hart (1896-1980), who took Lacan to task for rambling 'from Hegel to grasshoppers' and for descending into a state of 'neo-confusionism' (Hart, 1954). The other was a short book chapter on fetishism co-authored with Wladimir Granoff (1924-2000), which had in reality been written by Granoff alone, on the basis of extensive notes taken at Lacan’s lectures and seminars in Paris (Lacan and Granoff, 1956; Granoff, 1986; Nobus, 2003). Much like the first, this essay exuded Lacan’s intellectual audacity, his persistent drive towards theoretical innovation, and his exceptionally broad frame of reference, yet it did not stand out for its scholarly qualities nor, for that matter, as a landmark clinical statement. Defying the Anglo-Saxon psychoanalytic milieu's visceral aversion to conceptual abstraction and philosophical enquiry, this text too failed to leave its mark. It was not cited or discussed in any subsequent psychoanalytic accounts of fetishism.

When French structuralism became fashionable in the United States during the mid1960s, the name of Dr Lacan gradually started to circulate in anglophone countries, although primarily in academic departments of literature. Riding on the American structuralist wave, and its nebulous corrolary named 'French theory', Lacan's ideas captured the imagination of 
literature majors and graduate students in philosophy - alongside the works of Foucault, Barthes and Derrida. Nonetheless, English translations of his work remained piecemeal, and were largely confined to texts that were of direct relevance to questions of literary criticism, such as his 'Seminar on 'The Purloined Letter' (1972[1956]), and his interpretation of Hamlet (1977[1959]). The major exception to the rule was Anthony Wilden’s partial translation, with detailed annotations and commentary, of Lacan's seminal 'Rome Discourse' (Lacan 1956[1953]; Wilden 1968b, pp. 3-87), which was effectively based on his doctoral thesis (1968a), and which had been facilitated, if not altogether inspired, by Wilden’s being assigned the unenviable position of interpreter-designate and language-tutor for Lacan, when he was invited to speak at the first international colloquium on structuralism in Baltimore MD during mid-October 1966 (Lacan, 1970[1966]; Roudinesco, 1990[1986], pp. 411-412). By virtue of its academic excellence, its meticulous attention to the multifarious strands of thought running through Lacan's discourse, and Lacan’s own brief endorsement of it (Lacan, 1977[1970], p. vii), Wilden's book would become the standard introduction to Lacanian psychoanalysis for many an anglophone graduate student in the arts and humanities.

During the 1970s, the Pakistani-British psychoanalyst M. Masud R. Khan (1924-1989) was one of the very few, if not the only practicing psychoanalyst in the anglophone world who showed a marked appreciation for Lacan’s works (Hopkins, 2006, pp. 90-91). In the Spring of 1976, he arranged for an English translation of Lacan's Séminaire XI, Les quatre concepts fondamentaux de la psychanalyse (Lacan, 1973) to be included, with an additional preface specially commissioned by himself (Khan, 1982, p. 96), as volume 106 in the International Psycho-Analytical Library (Lacan, 1977[1973]). This was a long-standing, prestigious book series published under the aegis of the International Psycho-Analytical Association (IPA), from which Lacan had been officially expelled as a training analyst in November 1963, notably just a few months before the start of this very seminar (Miller, 1977). The momentous event and 
the tumultuous circumstances leading up to it (Attal, 2014) had shaped both the tone and the contents of Lacan's lectures, so it was supremely ironic for this seminar to be published under the auspices of the IPA, although Khan would have been very much aware of this. He may have even deliberately staged it as his own sweet revenge on the psychoanalytic establishment, which had placed him under investigation for recurrent professional boundary violations, and from which he too would eventually be expelled as a training analyst in January 1977 (Hopkins, 2006, pp. 298-300). Shortly before the English edition of Seminar XI was released, nine papers from Écrits cherry-picked by Lacan himself and covering his key contributions to psychoanalytic theory and practice from the 1950s had been published under the equally reputable Tavistock imprint (Lacan, 1977). This publishing house was originally established in 1947 as an outlet for members of the Tavistock Clinic and the Tavistock Institute of Human Relations in London, yet it had progressively expanded its list to a broader range of books in the human and social sciences, including works by R.D. Laing $(1927-1989)(1960,1961)$ and Michel Foucault (1926-1984) (1967[1961]; 1972[1969]) (Burfield, 2009).

As intellectual beacons for a new generation of French psychoanalysts, and as careerdefining statements for Lacan himself, the contemporaneous release of Seminar XI and the selected Écrits in English, combined with the English translation of the first doctoral dissertation on his entire oeuvre (Lemaire, 1977[1970]), could have triggered a torrent of newly commissioned translations, yet 1977 was hardly an annus mirabilis for Lacan in the Englishspeaking world. Whereas in 1966 his colossal Écrits had caused an unexpected sensation in the French bookstores, selling 5,000 copies in less than two weeks (Roudinesco, 1997[1994], p. 328), the heavily abridged English version failed to attract a large readership. ${ }^{2}$ Between 1977 , which could have inaugurated Lacan’s long-awaited English and American breakthrough, and

\footnotetext{
${ }^{2}$ As the editor of Tavistock Publications Ltd put it: 'In the case of both hardback and paperback editions [of the English Écrits], there was clearly a response to publication that was reasonably encouraging, but subsequently, an underlying rate of sale that has been very disappointing' (Smith, 1981).
} 
his death in September 1981, just a few stand-alone texts and a small handful of fragments from his seminar were published in English (see e.g. Lacan, 1979[1953]; 1980[1972]), some courtesy of Argentine Lacanians having settled in Australia (Lacan, 1980; 1981a; 1981b; Damousi, 2005, pp. 326-328; Ellingsen, 2013, pp. 169-170). In 1982, a seminal collection in English of mostly untranslated papers and seminar sessions by Lacan on feminine sexuality, spanning twenty-five years of psychoanalytic activity, was finally released to great acclaim, not in the least by virtue of the thorough introductions and annotations by the editors (Mitchell and Rose, 1982). This carefully assembled mélange of written and transcribed texts had been produced on the back of Lacan's recuperation as an intellectual figurehead by anti-essentialist feminist thinkers, and would prove hugely influential. But it did not result in a new major programme of translation.

\section{The French Psychoanalysis Series}

In September 1981, Dr John Forrester was a Research Fellow at King’s College, Cambridge with a passionate interest in psychoanalysis, especially Lacan's version of it. He had taken it upon himself to produce a full English translation of Lacan's early paper on logical time (Lacan, 2006[1945]), and was diligently working his way through the intermittent publications on Lacan's works in the English-speaking world. ${ }^{3}$ During the early 1970s Forrester had benefited from a Fulbright Scholarship to join the Programme in History and Philosophy of

\footnotetext{
${ }^{3}$ The Forrester papers in the Special Collections Division of the Albert Sloman Library at the University of Essex contain an annotated copy of a book chapter on Lacan by the influential French literature scholar Malcolm Bowie (1943-2007) - who also wrote one of the best short introductions to Lacanian theory (Bowie, 1991) - for an edited volume on structuralism (Bowie, 1979). One of the more interesting marginal comments by Forrester appears alongside Bowie's discussion of Lacan's reading of Edgar Allen Poe's 'The Purloined Letter', where it is written: 'cf. 3 prisoners'. This is an unambiguous reference to Lacan's essay on logical time, and it demonstrates how much Forrester was preoccupied with the text. See also Forrester (1990[1979]).
} 
Science at Princeton University, where he had attended the lectures of Thomas S. Kuhn (19221996) and Carl Schorske (1915-2015), whilst occasionally venturing out into the seminars of Richard Rorty (1931-2007), in a brave attempt at transgressing established disciplinary boundaries by adding some philosophy to history (Forrester 2017[2007]). By virtue of a Leverhulme Trust funded European studentship, he had also spent the academic year 1977-78 in Paris, during which time he had completed his doctoral dissertation on the largely neglected significance of linguistics and philology for Freud's historical construction of psychoanalysis (Forrester, 1980). In Paris, his enthusiasm for psychoanalysis had gone from strength to strength, although he had generally stayed away from Lacan's seminar 'Le moment de conclure' (Lacan, 1977-78), preferring instead Michel Foucault's lectures at the Collège de 'France on Security, Territory, Population' (Foucault, 2009[2004]). ${ }^{4}$ He had even gone so far as to ask Foucault in person about the reasons for his interest in psychoanalysis, yet only managing to extract a rather oblique answer (Forrester, 1990, p. 289 \& p. 317 note 2).

Forrester had concluded the published version of his thesis by saying that the conspicuous absence of the name 'Lacan' in a volume devoted to language and psychoanalysis had been a deliberate omission, partly inspired by the wish to capture the importance of speech and language for the origin of Freud's theory in its specific historical context, i.e. without Lacan's subsequent structuralist return to Freud, and partly in order to make room for 'a more direct approach to the Lacanian school of analysis' (Forrester, 1980, p. 211). In an echo of the allegory of the three prisoners in Lacan's paradigm of logical time, Forrester's dissertation had thus been the 'before' that would make possible the 'after', an 'after' that was 'kept waiting so that the before could assume its own place' (Lacan, 2006[1945], p. 161). Indeed, Forrester had explicitly conceived of Language and the Origins of Psychoanalysis as a prolegomena to

\footnotetext{
${ }^{4}$ Forrester accompanied Martin Thom to one of Lacan’s lectures at the Faculté de Droit of the Sorbonne, but there is no documentary evidence that he diligently attended on a weekly basis.
} 
Lacan, as a work of historical scholarship whose lens had been deliberately fixed backwards so as to generate a better understanding of Lacan's innovative Saussurean interpretation of Freud, and with a view to paving the way for a head-on engagement with the idiosyncrasies of Lacanian psychoanalysis.

It is the latter project that had been at the forefront of Forrester's mind for two years when, on 7 September 1981, two days before Lacan’s death, he wrote to Jacques-Alain Miller, Lacan's son-in-law and the general editor of his seminars, with a daring proposal (Forrester, 1981a). Enclosing a copy of his translation of Lacan's essay on logical time, and hoping for an opportunity to discuss the text with Miller and Lacan himself, Forrester expressed his wish to produce a new large collection in English of previously untranslated essays by Lacan, provisionally entitled Some Early Writings of Jacques Lacan. ${ }^{5}$ Some of the papers in the proposed collection had appeared in Écrits yet others had never been reprinted before. Forrester's project also included a text by the Hegel-scholar Jean Hyppolite (1907-1968) on Freud’s paper ‘Negation’ (Freud, 1961[1925h]), which had been presented at Lacan’s seminar on 10 February 1954 (Hyppolite, 2006[1956]), as well as the comprehensive accounts of Lacan’s seminars IV, V and VI by Jean-Bertrand Pontalis (1924-2013), which had been published regularly in the Bulletin de Psychologie between April 1957 and January $1960 .^{6}$ Whether it was Forrester's intention to translate all of these materials himself is not entirely clear from the correspondence with Miller, insofar as he indicated that he would also consult Alan Sheridan - the translator of Seminar XI and the selected Écrits - about the idea. Without awaiting Miller's reply, Forrester presented the project in turn to Gordon Smith, the then editor

\footnotetext{
5 See Appendix 1 to this essay.

${ }^{6}$ The only essay by Lacan in Forrester's proposal which had already been translated in English is the 'Seminar on "The Purloined Letter"” (1972[1956]). The two texts included in the proposal which had not been reprinted in Écrits are Lacan's 1938 encyclopedia contribution on 'The Family' (Lacan, 2001a[1938]) and a short paper from 1946 entitled 'Le nombre treize et la forme logique de la suspicion' (Lacan, 2001b[1946]), which may be read as a supplement to the essay on logical time. As of March 2017, both of these texts are still awaiting a full official English translation.
} 
of Tavistock Publications (Forrester, 1981b), and to Clifford Yorke (1922-2007) (Forrester, 1981c), who had replaced Masud Khan as the editor of the International Psycho-Analytical Library, after the latter had fallen out of favour with the British Psycho-Analytical Society.

The letter to Yorke commands attention, because in it Forrester explained how he envisaged the newly proposed collection of Lacan-essays to be 'part of a larger scheme to try to translate some of the more interesting psychoanalytic work that was influenced by Lacan, though not necessarily written by Lacanians’ (Forrester, 1981c). In this respect, he suggested three volumes: Psychanalyser by Serge Leclaire (1924-1994) (Leclaire, 1968), and Filiations and La pensée et le féminin by Wladimir Granoff $(1975 ; 1978) .{ }^{7}$ Again without waiting for his correspondents' replies, Forrester wrote back to Miller on 30 September 1981. Expressing his condolences on the death of Lacan, he told Miller how he had deplored the way in which the British press had failed to obtain a timely obituary. He then went on to say that he had also begun translating Lacan’s essay on 'The Family', and he asked Miller for various materials in support of a review of the imminent publication of Séminaire III, Les psychoses (Lacan, 1981c), which had been commissioned for the Times Literary Supplement (Forrester, 1982d). ${ }^{8}$ Keeping Miller abreast of his negotiations with Tavistock Publications and the International Psycho-Analytical Library, he disclosed that he was not very hopeful about receiving a positive response from the latter publisher, because 'Masud Khan, who is no longer with them, was the main mover overcoming their resistance and ensuring that at least something of Lacan appeared in their series’ (Forrester, 1981d). More optimistically, he also mentioned how he had recently started a conversation with editors at Cambridge University Press (CUP), on the basis of a preliminary outline of Lacanian psychoanalytic books to be translated under the heading 'French Psychoanalysis Series’ (Forrester, 1981d). Apart from The Early Writings of Jacques

\footnotetext{
7 The book by Leclaire was not translated until 1998; the books by Granoff remain unavailable in English. See Leclaire (1998[1968]).

${ }^{8}$ The manuscript of Séminaire III was finalised during Lacan's life-time, but the book was not published until after his death, which is why his picture appears on the cover of the French edition.
} 
Lacan, and the aforementioned titles by Leclaire and Granoff, the list now also included Études sur l'CEdipe by Moustapha Safouan (1974), L'amour de la langue by Jean-Claude Milner (1978), and L'inconscient malgré lui by Vincent Descombes (1977). ${ }^{9}$ For all I have been able to ascertain, Miller did not respond in writing to Forrester's letters of 7 and 30 September 1981. On 17 October 1981, Lacan's daughter Judith sent Forrester a brief note, in which she commented on the materials he had asked for, and expressed the hope of meeting him on the occasion of his visit to the Department of Psychoanalysis at the University of Paris VIII at the end of November (Miller, J., 1981). In the meantime, Gordon Smith had written to Forrester about his decision not to publish the proposed collection of Lacan essays (Smith, 1981), and although I have not found any written evidence of it, Clifford Yorke seems to have echoed his colleague's sentiment that the project could not be supported. Given the fact that Forrester ardently pursued his negotiations with CUP during the Winter months of 1981-82, he must have received the full support of Jacques-Alain Miller, who also did not hesitate to inquire about the status of the translation project when progress appeared rather slow (Miller, 1982a).

On 23 April 1982, Forrester was informed by Jonathan Sinclair-Wilson at CUP that the general response to the project had been favourable, although it had been suggested that the volume of Lacan translations should also include material from Lacan’s published seminars, and that of the six Lacanian books only Leclaire's should be considered for translation (Sinclair-Wilson, 1982). ${ }^{10}$ On 30 April 1982, Forrester wrote to Serge Leclaire about his plan to see Psychanalyser being translated into English, possibly with a new preface and a critical apparatus for the anglophone reader (Forrester, 1982a). ${ }^{11}$ On 11 May, Leclaire responded to

\footnotetext{
${ }^{9}$ Of these three books, only the one by Milner was eventually translated into English. See Milner (1990[1978]).

${ }^{10}$ It is worth noting here that the Belgian film-theorist Paul Willemen (1944-2012), who was one of seven (!) reviewers of Forrester's outline proposal, stated in a letter to Sinclair-Wilson dated 22 April 1982 that an entirely new, complete translation of Écrits was being prepared by Jacqueline Rose, rendering Forrester's initiative of a new selection potentially redundant, unless it was executed with some urgency. Needless to say, the latter initiative did not materialise. A complete English translation of Écrits was not released until 2006, in a translation by Bruce Fink. See Willemen (1982).

${ }^{11}$ Forrester had already met Leclaire at a two-day conference on telepathy organised by Peter Hildebrand (19282009) at Brunel University in July 1981, which had brought together the cream of the French intellectual crop,
} 
Forrester to say that he was extremely pleased with the initiative, and that he would take advantage of the opportunity to shorten the original text and combine it with some new materials (Leclaire, 1982). The day before, Forrester had written to Patricia Williams at CUP presenting a new project he had dreamt up in response to the reviewers' comments (Forrester, 1982b). Two possibilities were suggested: first, a book entitled The Jacques Lacan Reader, which would include a new selection of Lacan's writings, various excerpts from his published seminars, and the summaries of three other seminars produced by Pontalis; second, a complete translation of one or more of the published and previously untranslated seminars, i.e. seminars I, II, III or $X X$. Forrester's appetite for the first option was not great, partly because he could anticipate opposition from Miller, partly because he believed that the seminars' cohesion should not be disrupted by the extraction of fragments, however judiciously the process might be conducted. As to the second option, Forrester suggested that seminars $I$ and $I I$ should be given priority, because he felt that they contained Lacan's most accessible contributions to psychoanalysis. Alongside this letter, Forrester produced a new, comprehensive eight-page prospectus for the Press Syndicate for a book series entitled 'The French Psychoanalytic Tradition', in which he elaborated on the two options, again expressing his reservations as to the production of a Lacan reader, and arguing in favour of a full translation of seminars $I$ and II. Judging by a short note from Miller to Forrester dated 13 September 1982 (Miller, 1982b), it would appear that the Press Syndicate agreed to support the second option some time during the summer, yet they would not issue a contract until Forrester's translations had been checked and approved for accuracy. After a full year of negotiating, Forrester set himself to work on one sample chapter from each of Lacan’s first two public seminars.

including Jacques Derrida (1930-2004) and Hélène Cixous, alongside British psychoanalytic theorists such as Parveen Adams, Juliet Mitchell and Jacqueline Rose. 
As an addendum to this story, it is both interesting and amusing to note that, on 16 August 1982, Forrester sent his cherished translation of Lacan's essay on logical time to Thomas T. S. Hayley (1913-1993), the editor of The International Review of Psycho-Analysis, with the offer of writing an introduction to the text should the editorial board decide that it could be accepted for publication (Forrester, 1982c). On 31 January 1983, Hayley responded that, in light of the three peer-reviewers' evaluations, Lacan's essay could not be included. Justifying his decision, he attached some of the referees' comments. One anonymous referee had observed: 'I agree that Forrester seems to be brilliant ... But Lacan! Is it psychoanalysis? In any case, I don't think it would really interest psychoanalysts much . . .' Another had commented: 'The paper labours for far too long, though it does establish interesting points about how a judgment [sic] might be made. As it stands, however, it is simply a discourse on judgment [sic], unrelated to psychoanalytic technique or the theory behind the technique' (Hayley, 1983). A couple of days after receiving the letter of rejection from Hayley, Forrester sent his translation to the British philosopher Richard Wollheim (1923-2003), the Grote Professor of the Philosophy of Mind and Logic at University College London, who had just co-edited a collection of philosophical essays on Freud (Wollheim \& Hopkins, 1982), with the request for him to look at the essay with 'a philosopher's eye', and to recommend suitable publication outlets for it (Forrester, 1983a). I do not know what, if anything, Wollheim replied, yet Forrester's translation of Lacan's essay on logical time would never be published. ${ }^{12}$

\section{Translating Lacan's Seminar I and II: Forrester vs Miller}

\footnotetext{
${ }^{12}$ A new translation of the logical time essay was presented to Miller in 1984 by Bruce Fink. This translation was eventually published in 1988. See Lacan (1988[1945]).
} 
From the very beginning, Forrester realised that the quality of his translation would be greatly enhanced through the assistance of a native speaker or, better still, through a close collaboration with a perfectly bilingual scholar. And so he enlisted the help of his Cambridge colleague Sylvana Tomaselli, a Canadian historian specializing in eighteenth-century French and British political philosophy who had experience with translations. Forrester had first mentioned her in his letter to Patricia Williams of 10 May 1982, in which he clearly laid out the rationale for their cooperative work on Leclaire’s book and on the seminars: ‘[W]ith her linguistic skills and fluency in both languages [French and English], and with editorial backing up from me on technical vocabulary and intellectual background, one couldn't ask for a better translating setup [for the Leclaire book]. I would propose a similar set-up for the Lacan, but with the emphasis inverted: I would do most of the translation and she would be able to keep a check on the rhetorical, literary and argotic aspects of these infernal texts’ (Forrester, 1982b). After having obtained the agreement from Miller (1982c), this is how the translation project started, and how it would progress over the next three years. Forrester would produce a draft translation of the published French version of the seminars, send it to Tomaselli for checking, who would then comment in great detail on accuracy, consistency and idiomatic matters, which would facilitate a new, improved iteration of the text. Tomaselli herself would take primary responsibility for completing the translation of Seminar II. Forrester would also act as the main point of contact for Miller, CUP and du Seuil, and he would always be the one to mediate between the publishers, and to address issues of style and presentation. If Forrester's name appeared as sole translator of Seminar I and Tomaselli's as sole translator of Seminar II when the volumes were finally released in May 1988, it was merely for reasons of convenience, and not as an accurate reflection of the division of labour. As Forrester put it in a letter to Sinclair-Wilson of April 1985: 'It is really much of a muchness whether we take joint responsibility for both, or sole responsibility for one each’ (Forrester, 1985a). 
At the end of November 1982, Forrester sent Sinclair-Wilson a 'fairly final version' of the third chapter of Seminar I, with the promise that the sample chapter from Seminar II would follow soon (Forrester, 1982e). In April 1983, Sinclair-Wilson wrote back to Forrester with the good news that the French government had agreed to contribute towards the translation costs of each Lacan volume with a subsidy of 25,000 francs (some $£ 2,500$ ), and that a contract would now be drawn up. At the same time, he informed Forrester that in the absence of financial support for the translation of Leclaire's book, this part of the project would have to be postponed (Sinclair-Wilson, 1983). In the interim, Forrester had been told by Miller that the American publishers W.W. Norton \& Company had proposed to release all of Lacan’s seminars in the US, and that an agreement would need to be found between Norton and CUP over distribution rights and how the market could be shared (Miller, 1982c). Forrester wrote to the chief editor at Norton on 7 September 1983, asking about the status of the agreement and any specific translations that had been commissioned, so that he could work with the other translators on the production of a stylistically consistent text (Forrester, 1983b). The editor wrote back on 26 September to say that Patricia Fedkiw, an American literary critic and scholar of Marguerite Duras (1914-1996) (Fedkiw, 1982), had been contracted to translate Lacan’s Seminar III back in 1982, and that she was scheduled to submit her work by the end of the month. In addition, she stated that discussions had taken place between Norton and du Seuil over the translation of Seminar XX, yet without a firm agreement (Healey, 1983). Forrester received the full manuscript of Fedkiw's translation of Seminar III on 15 December 1983, yet it remains unclear whether he made direct contact with her.

On 16 February 1984, nearly a year after his first announcement that a contract for the translation of Seminars I and II would be forthcoming, Sinclair-Wilson finally sent the publishing agreement to Forrester and Tomaselli, with the caveat that CUP would still be under obligation to pass on the translations for final approval to Miller before they could be published. 
Sinclair-Wilson also indicated that he suspected Miller to be concerned about the introduction and the notes, yet that this would no doubt fall 'outside his or the French publisher's jurisdiction' (Sinclair-Wilson, 1984). As it turned out, Sinclair-Wilson's suspicion would set the tone for recurrent 'misunderstandings' between Forrester and Miller during the entire lifespan of the translation project. Forrester already got a taste of things to come when, on 2 March 1984, Prune Berge, the assigned editor at du Seuil, contacted him in order to clear up a 'misunderstanding' between Norton, Patricia Fedkiw and the French publishing house. In essence, Forrester was told that, back in January 1983, Miller had changed his mind over who should be responsible for translating Seminar III, and that he had now chosen the Australian philosopher Russell Grigg over Patricia Fedkiw. ${ }^{13}$ She went on to say that Grigg, strongly encouraged by Miller, had already started work on it, yet that all correspondence with Norton had remained unanswered. Asking Forrester whether he had seen Fedkiw's translation, what he thought of it, and what his own intentions were with regard to editing this volume and translating Seminar $X X$, she then reminded him of the fact that Miller would reserve the right to stop its publication should he deem it unsatisfactory (Berge, 1984). Forrester responded ten days later with the message that he had indeed scrutinized Fedkiw's translation of Seminar III, and that he believed it to be virtuous, very careful and faithful to the original, yet perhaps a bit too academic in light of the flowing, 'distinctive easiness of Lacan’s speech'. 'Unless Russell Grigg’s translation is entirely complete,' he continued, 'I think the Fedkiw work can be taken as a satisfactory basis for the eventual translation. Such a comment is entirely subject to the

\footnotetext{
${ }^{13}$ The letter stated: 'Comme vous le savez sans doute, en effet, Norton a demandé à Madama Patricia Fedkiw de traduire le Séminaire III de Lacan en octobre 82. En janvier 83, Jacques-Alain Miller nous a demandé de faire en sorte que ce soit Russell Grigg qui traduise ce Séminaire' (Berge, 1984). Grigg had written to Lacan c/o the Department of Psychoanalysis at the University of Paris VIII during the mid-70s, inquiring about the possibility of his applying for a Doctorat de $3^{\mathrm{e}}$ cycle. Miller, in his capacity as Head of Department, had replied to Grigg, and had agreed to supervise Grigg's project. When Grigg defended his doctorate in 1982, he told Miller that he would be interested in translating one of the seminars, and Miller suggested that he take on Seminar III. Without being aware of the fact that Norton had already issued a contract to Fedkiw for the translation of a book by Lacan called Séminaire III, he himself received a contract from Norton for the translation of Les psychoses. The details of the two contracts, much like the information in the following note, are based on a personal conversation with Russell Grigg.
} 
proviso that I have not seen Russell Grigg's work, which may well be so far superior as to demand that one cede it pride of place' (Forrester, 1984). ${ }^{14}$ In response to the editor's other questions, Forrester pointed out that he himself would not mind editing Fedkiw’s translation, and that he had also been considering a translation of Seminar XX, as well as Seminar VII, whose publication in French had already been announced. ${ }^{15}$

Sinclair-Wilson sent Forrester and Tomaselli the formal publishing agreement on 16 February 1984. Under paragraph 2, the contract stipulated that 'Dr. Forrester shall have overall responsibility for the Work, and shall supply an introduction and notes'. The translators were also being asked to submit the typescript by 1 April 1984, yet this timescale proved unrealistic. Forrester sent the typescript of his translation of Seminar I to both Miller and Sinclair-Wilson in early February 1985, ten months after the contractual deadline. Forrester had already informed Miller the month before that the completed manuscript of Seminar I would be imminent, when the two met on the occasion of a two-day conference on 'Transmission and Psychoanalysis’ in Cambridge. Held at Trinity College on 4-5 January 1985, and organised by Darian Leader, who was still an undergraduate student at Downing College, under the auspices of the Cambridge Psychoanalytical Study Group, this was effectively the first ever large-scale Lacanian conference in the UK. ${ }^{16}$ It brought together a diverse group of French (Lacanian) psychoanalysts and Lacan-scholars - Conrad Stein (1924-2010), Daniel Sibony, Alain Juranville, Eugénie Lemoine-Luccioni (1912-2005) - whilst also creating a platform for

\footnotetext{
${ }^{14}$ When Fedkiw's translation was sent to du Seuil and Miller, the latter asked Grigg what he thought of it. Grigg responded that he did not like it very much, and in the end the contract with Fedkiw was declared null and void, and her translation was relegated to the archives. Grigg did not draw on Fedkiw's previous translation when he pursued his own work. In 1993, the English translation of Seminar III was published by Norton, without any mention of the fact that there had been an earlier version of it which had been discarded. See Lacan (1993[1981]). ${ }^{15}$ In the end, Seminar VII was not published until September 1986. See Lacan (1986).

${ }^{16}$ Although it was by no means the first Lacan-event in the UK. In June 1984, Brett Kahr, then Research Officer at the Littlemore Hospital and Director of the 'Oxford Psychoanalytical Forum', had already organised a day conference called 'Introducing Lacan' at the University of Oxford, which had included presentations by Terry Eagleton, Toril Moi and John Forrester amongst others. This multidisciplinary and multi-media event had attracted more than a hundred people, and had even involved a staged performance of one of Lacan's clinical presentations (Lacan, 1980[1976]).
} 
established and emerging psychoanalysts and psychoanalytic scholars from different orientations in the anglophone world, such as Brett Kahr, Bice Benvenuto, Richard Klein, Roger Kennedy, Elizabeth Wright (1928-2000) and Teresa Brennan (1952-2003). ${ }^{17}$ Forrester presented a paper entitled 'Anonymity and Psychoanalysis', and Miller delivered the closing address under the title 'The Mainstream of Lacan's Thought'. With some 180 delegates attending, the group was large, yet the gathering also sufficiently intimate for everyone to get a chance to know one another, and for Forrester to update Miller on his translation project. On 19 February 1985, Miller wrote to Forrester thanking him for the typescript, and indicating that on first sight he was delighted with the quality of the translation, which he considered to be well-produced, idiomatic and exact. He also told him that Grigg would take a copy back to Australia in order to read through it, and that for the time being he only had two critical comments to make: some of the notes seemed unnecessary, and the idea of designating Forrester on the title page as the responsible editor for the English edition of the seminars did not appeal to him, since this was the right he would want to reserve for himself. ${ }^{18}$ Finally, he invited Forrester to become part of a ‘Translation Committee’ (Comité des traducteurs), which would also comprise Grigg and the Irish Jesuit psychoanalyst Cormac Gallagher, who had been

\footnotetext{
${ }^{17}$ Following the conference, Darian Leader joined hands with Bice Benvenuto, Bernard Burgoyne and Richard Klein to create the Centre for Freudian Analysis and Research (CFAR), the first Lacanian training organisation in the UK, which continues to flourish to this day. Eight years after the conference, Sibony wrote about his experience at Cambridge in Le peuple 'psy': 'One day I was invited to Cambridge alongside Lacan's son-in-law. My talk was well-received, to the point where the young people responsible for the conference were happy to confide in me. The son-in-law had told them off for having invited me: "It shouldn't have happened. He is not a real Lacanian. He was invited because of his texts”. The next day I attended the son-in-law's paper, in which he repeated, as always, the discourse of his master, albeit punctuated with some "mathemes" and with a rather apposite label: "I am his son-in-law" [In English in the original]. It is meant to be understood as: I am his son according to the Law. A good way of sending shivers down the spine of those neurotics who crave the Law. I made some very precise critical comments, to which he did not respond - analytical silence - much like his master, to the surprise of those people who still believed in debate and in "scientific" argument. The English hosts were shocked by this silence. Yet two days later I noticed how they were slightly embarrassed, a trifle distant even, and I rapidly understood the reason. The son-in-law and his militants had been working on them by selling them a label. They would be the Lacanian School of Cambridge. A solid identity. Why not?' (Sibony, 2007[1993], pp. 143-144). I am grateful to Darian Leader for sharing his recollections, and for referring me to the book by Sibony. ${ }^{18}$ Grigg checked the entire manuscript and forwarded a few minor suggestions for improvement to Miller, but did not enter into direct correspondence with Forrester.
} 
translating Lacan's text on 'The Family' (Miller, 1985a), and who had also attended the conference in Cambridge earlier that year. ${ }^{19}$

Upon receipt of his copy of the typescript, Sinclair-Wilson inquired about Forrester’s introduction, bibliography and a possible glossary, and he suggested that both the French pagination and the different typefaces for commentaries made by Lacan's interlocutors be removed, in order to reduce the production costs (Sinclair-Wilson, 1985). In his response of 9 April, Forrester considered Sinclair-Wilson's suggestions, and also reminded him that he would inquire about the possibility of including, as an appendix to Seminar $I$, the text of Hyppolite’s commentary on Freud’s ‘Negation’ (Freud, 1961[1925h]) of 10 February 1954 (Hyppolite, 2006[1956]), which had been reprinted as an appendix in the French Écrits (Hyppolite, 1966[1956]), but not in the original edition of Seminar I (Forrester, 1985a). Five weeks later, Forrester wrote back to Miller with the news that the translation of Seminar II would be ready by early June, yet that both volumes would now not be released until the year after. He also apprised him of the fact that he was still keen to translate Seminar VII, and that on Saturday $11^{\text {th }}$ May he had given some lectures for the Department of Psychiatry at St. Vincent's Hospital in Dublin, where he had discussed the idea of setting up a Translation Committee with Cormac Gallagher (Forrester, 1985b). ${ }^{20}$ Shortly afterwards, Forrester inquired with Presses Universitaires de France about the rights to include Hyppolite’s paper, for which

\footnotetext{
${ }^{19}$ Gallagher had attended Lacan's seminars during the 1970s, following a meeting with Louis Beirnaert SJ (19061985), and he had also trained as a Lacanian psychoanalyst in Paris, whilst pursuing a doctorate under the supervision of Jean Laplanche (1924-2012). In 1983, he had co-founded the School of Psychotherapy with the psychiatrists Noel Walsh (1934-2015), Michael Fitzgerald and Mary Darby of the Department of Psychiatry at St. Vincent's Hospital in Elm Park, Dublin. Gallagher effectively introduced Lacanian psychoanalysis in Ireland, and would conscientiously go on to translate twenty of Lacan's seminars and many of Lacan's writings in an unofficial version, in support of the School's work. Gallagher's translations never received Miller's formal approval, but they are available at www.lacaninireland.com. Although Miller's 'Translation Committee' did not come to fruition, he asked Grigg to review Gallagher's translation of 'The Family', and Grigg also produced an English-language version of its bibliography. The text was eventually completed, but the translation was never officially published. Until this day, the essay remains unavailable in an official format in English.

${ }^{20}$ Gallagher had invited Forrester to Dublin when they met in Cambridge (Gallagher, 1985a), and Forrester had gladly accepted the opportunity to go and speak about his work to a small group of Irish clinicians, whilst also sharing his translation of Lacan's essay on logical time with his host (Gallagher, 1985b).
} 
he received formal permission on 10 July (Lays, 1985). Over the summer, Miller scrutinized the entire text of Seminar I and II, and reviewed a list of questions Forrester had sent him under separate cover. Some of the questions referred to possible misprints in the original French edition, whereas others pertained to issues of vocabulary and phrasing, and others asked for additional information on people, places and sources. ${ }^{21}$ Sometimes Miller would accept that there had been a misprint in the French edition - as when Freud's German term verdrängt had been rendered as verdankt (Lacan, 1975, p. 311) - and at other times he would provide the additional information requested. Sometimes he would clarify an allusion, yet refusing to allow Forrester to provide a note to that effect, and at other times he would simply indicate that he could not give any more details.

The first signs of a major disagreement between translator and editor became apparent in a letter Miller sent to Forrester on 20 September 1985. In it, Miller stated categorically that he would not allow Forrester's contextualising interpretive introductions to be included with the English translations of Seminars I and II, in conformity with how other foreign-language editions of the seminars had been released, and much like Grigg had accepted for his forthcoming translation of Seminar III. Miller also disclosed that he had chosen Dennis Porter, Professor of French Critical Theory at the University of Massachusetts Amherst, to translate Seminar $X X$, and that Porter too had agreed with the principle that the seminars should be released without an introduction. ${ }^{22}$ Referring to Forrester's introductions as 'personal reflections inspired by the text', he argued that these should be published separately, in journals or as part of monographs (Miller, 1985b). The first part of these introductions, which Forrester

\footnotetext{
${ }^{21}$ For example, when Lacan alluded in Seminar I to a person who had written on technique, and whom he had mentioned before, yet without repeating the name of the person in question (Lacan, 1975, p. 21), Forrester asked Miller to clarify the issue. Or, when in Seminar II Lacan referred to the 'service' where the seminar was taking place (Lacan, 1978, p. 283), he checked his understanding and asked Miller for more information.

${ }^{22}$ Miller had met Porter at a three-day international Lacanian meeting at the University of Massachusetts Amherst in the middle of June 1985. Instead of Seminar XX, Porter would go on to translate Seminar VII, which would be published in English in 1992. See Lacan (1992[1986]).
} 
wanted to see included in both seminars, contained a succinct intellectual biography of Lacan, retracing his major influences and detailing his acrimonious struggles with the IPA, as well as a synopsis of his theory as a whole, and some suggestions for further reading. The second part, which was to be specific for each seminar, set the lectures in their historical context and summarized Lacan's main arguments. But Miller refused to authorise any of this as part of the publication.

Of course, back in February 1984, Sinclair-Wilson had already mentioned that Miller might be critical of the introductions, yet when the contract was issued and signed (although not by Miller), it had been stated unequivocally that Forrester was expected to write introductions to both seminars alongside the translations. As such, Forrester had fulfilled his contractual commitments, and now found himself in the awkward position of having to find alternative outlets for his scholarly labour. Six days after this first letter, Miller sent Forrester another one, in which he repeated that he would not accept Forrester's 'personal commentaries', which would find their proper place in a scholarly article for a learned journal. He also made a series of additional observations regarding the critical apparatus: 1 . providing bibliographical details for the references to Freud's works would be acceptable, but for the other source materials it remained questionable; 2. in those places where the original French text contained errors, they could only be corrected silently, i.e. without the English version highlighting that there had been a transcription error, or that Lacan had been mistaken; 3 . essential translator's notes, emphasizing alternative options or readings, would also be allowed; 4. Lacan's algebraic notations and mathemes (such as $A$ and $m$ ) should not be translated, in accordance with Lacan’s own indications. Enclosing his ‘screening' (criblage) of the notes for Seminar II and promising to send over his remarks on Seminar I shortly, Miller ended with the following reminder: 'I haven’t approved your translation yet. I'm waiting for a definitive and exhaustive copy, which takes on board in a precise way the indications I've given you' (Miller, 
1985c). Over the next two months, Miller’s position was repeated to Forrester three times over, from three different sources: his personal secretary (Doisneau, 1985) and two editors at du Seuil (Gerschenfeld, 1985; Berge, 1985). Sinclair-Wilson replied to one of these missives trying to justify the inclusion of Forrester's editorial matter, yet Miller remained adamant that he would only agree to the seminars being published on condition that all his instructions would be followed to the letter. By way of explanation for his decision, he forwarded Sinclair-Wilson a copy of a recently published interview on his edition of Lacan’s seminars (Miller, 1985d).

Unphased by Miller's remarks, waiting for the publishers to try and come to some form of agreement, and never afraid to argue his case in forceful terms, Forrester wrote a seven-page letter to Miller on 2 February 1986, in a final attempt to persuade him to change his mind (Forrester, 1986a). ${ }^{23}$ Now it was Forrester who reminded Miller that the contract issued by CUP had explicitly requested for notes and introductions, and that he had fulfilled his contractual duties. Yet he also raised various other arguments in support of a full critical apparatus: it would make Lacan’s work more accessible to English-speaking readers; it was in keeping with the high editorial standards of CUP; it would be of invaluable assistance to the reader wishing to work with both the French and the English texts; it is normal practice amongst British and American scholars. One month after Forrester's lengthy justification for a full critical apparatus, Miller replied curtly by saying that his position would not change, that he possessed the means to validate it if necessary, and that Forrester should not spoil his chances of carrying on working with him by entering into a futile polemic (Miller, 1986a).

Forrester and Miller had a chance to discuss their divergences of opinion in person during the weekend of 12-13 April 1986. Following the resounding success of the Cambridge conference, the creation of the Centre for Freudian Analysis and Research (CFAR), and the launch of a new Centre for Psychoanalysis at what was then Middlesex Polytechnic, the

\footnotetext{
${ }^{23}$ See Appendix 2 to this essay.
} 
founding members of CFAR led by Bernard Burgoyne organised a second international conference simply entitled 'Lacan in England', at the old Elizabethan hunting lodge of Trent Park in North London. ${ }^{24}$ Compared to the diverse range of presenters at Cambridge, this second Lacanian conference in the UK could not be more different, insofar as Miller had instructed the CFAR board that it was time to purify, and that all the speakers would have to be either directly affiliated with his École de la cause freudienne, or expressly approved by him. Some 200 people descended upon the English country house, and the atmosphere was charged with the promise of great things to come. Forrester was in high spirits because he had recently become a father, and he was still hoping to change Miller's mind. Driving him around London, and walking under the Spring sunshine amongst a yellow sea of daffodils in Trent Park's surrounding grounds, Forrester explained himself, and Miller listened, but in the end the two men just agreed to disagree. Miller was not prepared to compromise (Miller, 1986b). ${ }^{25}$

During the following months, Forrester considered alternative venues for his introductions, and settled some outstanding issues with Miller, such as the bibliography and the Hyppolite paper (Forrester, 1986b). On 20 June, Miller agreed that the latter could be included, and he also gave Forrester permission to add a note explaining the dotted lines in the original (Miller, 1986c) ${ }^{26}$ Over the Summer, Forrester sent Miller the definitive version of both seminars for final approval. The week before Christmas, page proofs for both volumes were forwarded to Forrester for revision and indexing (Futter, 1986), which would take up most of his time over the next six months. Miller himself did not give CUP his final approval until the Summer of 1987. In August of that year, Forrester informed him that copies of the

\footnotetext{
${ }^{24}$ The conference was advertised as 'the first English language debate to be held in London on the problems and perspectives present in Lacan's orientation to psychoanalysis'.

${ }^{25}$ My account of the 'Lacan in England' conference is based on conversations with Lisa Appignanesi, Bernard Burgoyne and Darian Leader.

${ }^{26}$ Miller suggested that Forrester use the following gloss, which was not retained in the published version of the seminars: 'Participants' interventions at the seminar have occassionally been abridged by J.-A. Miller; these omissions are signalled by dotted lines’ (Miller, 1986c).
} 
books would be available by December, or in January the following year. He also told him that the disputed introductions would be published imminently in a slightly amended form, in two successive issues of the journal Free Assocations (Forrester 1987a; 1987b; 1988). ${ }^{27}$ As it turned out, Forrester had been too optimistic. The English translations of Seminar I and II were published simultaneously in the US on 1 May 1988, and in the UK on 19 May 1988, almost six years after the project was first initiated (Lacan, 1988[1975]; 1988[1978]). As Forrester had suggested to Sinclair-Wilson in April 1985 (Forrester, 1985a), Volume I appeared as having been translated solely by John Forrester, and Volume II as solely by Sylvana Tomaselli, although with notes prepared by John Forrester. Both books contained a comprehensive bibliography, a brief translators' [sic] note dated June 1986, a detailed index, and those footnotes which Miller had approved, yet without the contentious introductions, and without any indication to the reader that detailed introductory essays to the books could be found elsewhere. As an appendix, Volume I also reprinted Hyppolite's presentation at Lacan's seminar (Hyppolite, 1988[1956]). ${ }^{28}$ Acknowledgements were only included in Volume II, and here the translators thanked CUP, its editors and copy-editor, as well as Miller 'for the meticulous attention to detail manifested in the substantial advice he has given’ (Lacan, 1988[1978], p. ix). Sales of the books were not as good as they had been for Lacan’s Écrits in 1966, but nonetheless satisfactory. During the first year after publication, Seminar I sold 2,612 copies in hardcover and 795 copies in paperback, whereas Seminar II sold 2,614 in hardcover and 749 in paperback (Christiansen, 1989).

\footnotetext{
${ }^{27}$ Both introductions were thus published before the Seminars came out, and were subsequently reprinted as a single essay in Forrester's The Seductions of Psychoanalysis. See Forrester (1990[1987-88]). When Forrester made the decision to release his introductions as separate papers, he chose the title 'In Place of an Introduction' as an echo of the opening chapter of Kojève's Introduction to the Reading of Hegel. This was the only chapter written and published by Kojève himself, as a translation with commentary of Section A of Chapter 4 (Part B) of Hegel's Phenomenology of Spirit. See Kojève (1969[1947], pp. 3-30), Hegel (1939), Hegel (1970[1807], pp. 145155). Forrester highlighted the allusion in a letter to Miller of 23 March 1991 (Forrester, 1991).

${ }^{28}$ A new translation of this text by Bruce Fink was subsequently included in the English translation of the complete Écrits. See Hyppolite (2006[1956]).
} 
By way of addendum to this part of the historical narrative, one additional fraught translation initiative of Forrester's is worthy of mention. As soon as he had finished with the final version of the English translation of Lacan's first two public seminars, Forrester embarked, with Miller’s acquiescence, upon the translation of Lacan's Television - a very short, yet hugely complex book originally published in 1974 as the edited text of two one-hour presentations by Lacan for France's main television channel ORTF (Lacan, 1974) - which would serve as the main contribution to a special issue of the American journal October, published by the prestigious MIT Press (Copjec, 1986a). Forrester received a contract for his translation from MIT in July 1986, and he arranged to discuss the project with Miller in early October (Miller, 1986d). He sent the manuscript to the journal editors and to Miller shortly afterwards (Forrester, 1986c), and prepared a short translator's note dated 25 November 1986 in which he pointed out that, following Miller's request, Lacan’s term jouissance had been left untranslated (Miller, 1986d), yet that the portmanteau word lalangue had been rendered as 'universal babble'. However, things did not go as planned. At the beginning of November, Forrester's translation was scrutinized by two of the magazine's editors, as well as by Denis Hollier, a US based French academic who had attended some of Lacan's seminars during the 1970s. On 12 November, Forrester was informed that Hollier's corrections to the translation had been so extensive as to warrant its being published as a collaborative enterprise (Copjec, 1986b). Forrester replied six days later to express his surprise and dissatisfaction with the way in which his work had been handled, agreeing to acknowledge Hollier, but refusing to the proposed sharing of translation credits (Forrester, 1986d). Three weeks later, he received a letter co-signed by the three editors of October, in which he was told that his translation had required 'massive rewriting' and that, as a result, his name would now not be retained at all (Michelson, Krauss \& Copjec, 1986). Lacan’s Television was eventually published in English in the Spring 1987 issue of October - a year before the translations of Seminar I and II - as 
having been translated jointly by Denis Hollier, Rosalind Krauss and Annette Michelson (Lacan, 1987[1974]). Three years later, Norton re-released the journal issue in book format (Lacan, 1990[1974]). Neither of these volumes mentioned anything about the translation being based upon, or having been originally produced by Forrester. ${ }^{29}$

\section{Conclusion}

Both in his first letter to Miller, and in his elaborate response to CUP's reviewers of his original proposal for a wide-ranging book series on French psychoanalysis, Forrester presented himself as a dedicated scholar, with a clear vision of how Lacan's English reception should be facilitated. If 'The French Psychoanalysis Series' died a silent death, so much so that the initiative was literally relegated to the archives, it is primarily owing to a lack of support, or persistent opposition from external stakeholders, i.e. publishers, editors and referees, some of whom were psychoanalysts themselves. There is no evidence that Lacan's heirs, including his designated intellectual successor, interfered with this part of the project, despite the fact that (as Forrester himself realised) the integration, into the proposed collection of writings by Lacan himself, of Pontalis's summaries of Lacan's seminars from the late 1950s, could very well have proved a deal-breaker. When the proposal shifted from a broad outline to a concrete project plan, and from a series of books in translation to the translation of Lacan's first two public seminars, the editorial questions also changed. Now, the issue was not whether Lacan and his followers could be reintroduced 'profitably' into the anglophone world, but how Lacan's work should be framed and presented to an English-speaking readership. At this point, the resistance to Forrester's (heavily reduced) vision became internal, insofar as the swift execution of the

\footnotetext{
${ }^{29}$ For reasons of space, I cannot reconstruct the entire history of Forrester's translation of Television here. I shall reserve the finer details for another occasion.
} 
project was hampered by ongoing 'misunderstandings' between Forrester and Miller. By virtue of his contextualising introductions and his detailed annotations, Forrester wanted to be more than a simple translator. Rather than merely rendering the text of Lacan's seminars into idiomatic English, with the odd translator's note, he wanted to secure an equitable critical reception of the works through the addition of a comprehensive scholarly apparatus. When it came to arguing his case, Forrester could have drawn Miller's attention to the fact that many of the essays by Lacan that had appeared in English during his lifetime had been published with extensive introductions, and that in the case of the 'Rome Discourse', an incomplete translation of the text had even been combined with an introduction and a large-scale interpretive commentary. He could have reminded Miller that Lacan himself did not seem to have interfered with the way in which these texts had been released, yet he chose not to do so. Indeed, Lacan may have given Miller some instructions as to how his seminars should be edited and published in French (Miller, 1985), but it was not at all clear that he had held strong views about their presentation in other languages. Be that as it may, Miller refused to authorise the inclusion of Forrester's introductions, yet he did agree to some scholarly notes, an index, a bibliography and the Hyppolite paper.

At this point, readers might expect to see my reconstruction of the historical record being employed as a basis for the articulation of some form of judgement about who was right and who was wrong. If I shall refrain from doing so, it is not because I think historiography can and should be devoid of interpretive narration. Indeed, my account of the historical circumstances leading up to, and the acrimonious discussions surrounding the English translation of Lacan's first two public seminars in the preceding pages, balanced and nuanced as I have tried it to be, is undoubtedly already refracted by my own subjective perspective on the events, despite the fact that I did not directly participate in any of the aforementioned happenings and debates. One day, another researcher may go through the various letters and 
documents in Forrester's archives, and produce a rather different picture of how the translation project progressed. Furthermore, if I shall not pass judgement on the key players in this project, it is not because I do not have a strong opinion as to how Lacan's seminars should be presented to an anglophone readership, nor because I am unable to decide which side of the argument pertaining to the inclusion of a scholarly apparatus is more compelling, and how extensive the scholarly apparatus should be when it comes to rendering Lacan's works in English. Given my own attempts at producing annotations to the translation of one of Lacan's more challenging writings (Lacan, 2013; Nobus, 2013), in a separate yet juxtaposed 'bibliographical essay', readers may even draw certain conclusions about my position, although what applies to the translation of an exceptionally labyrinthine written text should not necessarily be extrapolated to the translation of a reasonably accessible set of transcribed lectures. If I shall refrain from passing judgement on the dramatis personae of the aforegoing saga, it is quite simply because I want readers to judge for themselves how Lacan's seminars should have been presented, whether Miller's persistent objections to Forrester's contextualising introductions were justified, and whether the entire project was handled correctly by editors, publishers and translators. Rather than adjudicating between rival positions, it may thus be more interesting for me to synthesize some key points, and to open a broader perspective on the way in which Lacan's seminars have been produced since the first French publication of Seminar XI, in 1973. As of March 2017, sixteen out of twenty-seven volumes of Lacan’s seminar have been officially released in French. Of those sixteen, ten are currently available in an official English translation. During Lacan's lifetime only four of his seminars were published in French, and only one in English. In all likelihood, the latter would never have seen the light of day had it not been for Masud Khan's intellectual infatuation with Lacan. It is definitely the case that Seminar XI would never have been published under the auspices of the IPA without Khan's personal involvement, and without his own intrepid defiance of the psychoanalytic 
establishment. When Seminar XI eventually came out in English in 1977, it contained a newly commissioned preface by Lacan himself, which was hardly fit for purpose, since it did not provide any historical details as to what had prompted him to address the foundations of psychoanalysis, notably his ‘excommunication' from the IPA as a training analyst. As Khan put it in 1982: 'The hope of the Editor [i.e. himself] to elicit a Preface that might have helped the English-reading audience was not so much defeated, as confounded, by the additive Lacanian text' (Khan, 1982, p. 96). The English edition of Seminar XI did not reproduce Lacan's postface, in which he explained how the edited transcription should be approached, and which role Miller had played in its conception (Lacan, 1973, pp. 251-254), nor Lacan’s own summary of the seminar for the yearbook of the École pratique des Hautes Études, which had been published on the back cover of the French edition, but it did contain Miller's short ‘editor’s note’ (Lacan, 1977[1973], p.xi). ${ }^{30}$ Unlike the French edition, the English translation did include a glossary of key Lacanian terms, such as the Imaginary, the Symbolic and the Real, as well as a comprehensive index of names and concepts, alongside a brief translator's note. Apart from that, the scholarly apparatus (explanatory notes, alternative readings, bibliography) was non-existent. I have not found any evidence that Lacan and/or Miller left instructions to the translator and/or the publisher as to how this English version should be presented, nor have I come across any comments by Lacan and/or Miller as to what they thought of the translation - its quality and/or style of presentation. However, when the book was reprinted in a mass-market paperback edition by Penguin in 1994, it contained a new lengthy introduction by David Macey (Lacan, 1994[1973], pp. vii-xxxviii), which was not all that dissimilar in style to the introductions produced by Forrester for Seminars I and II. This

\footnotetext{
${ }^{30}$ For an English translation, with commentary, of Lacan's summary, see Gallagher (1995). For an English translation of the postface, see Lacan (2012[1965]).
} 
new English version of Seminar XI therefore comes close to the type of book Forrester had in mind, were it not for the almost complete absence of notes and a bibliography.

The twelve volumes of Lacan's seminar that have been published in French since his death have also changed in style and conception over the years, although perhaps not as dramatically as some people would have wished. Since March 2005, with the publication of Seminar XXIII (Lacan, 2005), all volumes have contained an index of names, as well as glosses and commentary by Miller, and on occasion 'reading notes' by others. Sometimes the commentary has been presented as ‘A Note Threaded Stitch by Stitch’ (Miller, 2016[2005]), whereas at other times it has been called 'Help for the Reader' (Miller, 2006a), 'Some References ...' (Miller, 2006b), ‘Library’ (Miller, 2011) and ‘Marginalia’ (Miller, 2013). Save the aforementioned new English edition of Seminar XI, none of the nine seminar volumes that have since appeared in English contain contextualising interpretive introductions, and Miller has made it crystal-clear to his chosen translators that none should be provided, or that these should be published elsewhere. However, the content of the translator's notes has varied significantly from one volume to the next, giving the reader the impression that Miller has been more flexible and accommodating with some translators (or perhaps with some volumes-intranslation) than with others. For example, the translator's notes provided by Bruce Fink for his translation of Seminar $X X$ rarely extend beyond alternative readings and bibliographical references (Lacan, 1998[1975]), whereas Adrian Price’s notes to his translation of Seminar XXIII occasionally point out that Lacan's usage of certain terms and designations is imprecise and requires correction (Lacan, 2016[2005], pp. 222-231). Another inconsistency is that since 1993, only one Lacan seminar in English has included a bibliography, namely Grigg's translation of Seminar XVII (Lacan, 2007[1991]).

When Forrester decided to reprint his vexed introductions to Seminars $I$ and $I I$ as a single essay in The Seductions of Psychoanalysis, he prefaced the text with a new 'Note on 
Translation', which opened with the following lines: 'I had intended to pay off my debts to Jacques Lacan in the long hours of wrenching back from his texts a version of his alien meaning which would smooth the way for others like myself. I set out to translate, to render his words, violently, into another language. I did not anticipate that, rather than paying them all off, I would instead incur more debts’ (Forrester, 1990, p. 99). Forrester went on to explain his 'translation philosophy', insisting on his firm belief that there is no such thing as an untranslatable word in any natural language, yet clarifying that 'editorial work' on the originals had imposed itself, especially with a view to generating an accurate, error-free text. Without holding back, however, he also disclosed how Miller had prevented him from explaining allusions, indicating factual errors, and rectifying Lacan's occasional Freudian slips in the original: "All vetoed and censored, although they have been "silently" corrected in the English translations - whence the promise to "correct" eventually the original French editions' (Forrester, 1990, p. 101). A corrected French edition of Seminars I and II on the basis of Forrester's translations remains outstanding, and so in this respect too Forrester did not succeed in paying off his debts. Nonetheless, countless anglophone psychoanalysts and scholars around the world remain indebted to him for transmitting through translation a meticulously produced edition of Lacan’s first two public seminars.

\section{References}

Attal, J. (2014) Le rapport Turquet. Trans. with notes from the English by L. Parisel. Paris: Cahiers de l'Unebévue.

Berge, P. (1984) Letter to John Forrester of 2 March 1984. John Forrester Papers, Albert Sloman Library. University of Essex. Box 42.

Berge, P. (1985) Letter to Jonathan Sinclair-Wilson of 7 November 1985. John Forrester Papers, Albert Sloman Library. University of Essex. Box 42. 
Bowie, M. (1979) Jacques Lacan. In J. Sturrock (ed.), Structuralism and Since: From LéviStrauss to Derrida. Oxford: Oxford University Press, pp. 116-163.

Bowie, M. (1991) Lacan. London: Fontana Press.

Burfield, D. (2009) Tavistock Publications: A Partial History. Management \& Organizational History, 4(2), pp. 207-222.

Christiansen, S. (1989) Letter to John Forrester of 12 May 1989. John Forrester Papers, Albert Sloman Library. University of Essex. Box 42.

Copjec, J. (1986a) Letter to John Forrester of 18 July 1986. John Forrester Papers, Albert Sloman Library. University of Essex. Box 92.

Copjec, J. (1986b) Letter to John Forrester of 12 November 1986. John Forrester Papers, Albert Sloman Library. University of Essex. Box 92.

Damousi, J. (2005) Freud in the Antipodes: A Cultural History of Psychoanalysis in Australia. Sydney: University of New South Wales Press.

Descombes, V. (1977) L'inconscient malgré lui. Paris: Minuit.

Doisneau, É. (1985) Letter to John Forrester of 7 October 1985. John Forrester Papers, Albert Sloman Library. University of Essex. Box 42.

Ellingsen, P. (2013) A History of Psychoanalysis in Australia: From Freud to Lacan. Victoria: PsychOz Publications.

Fedkiw, P. (1982) Marguerite Duras: Feminine Field of Hysteria. Enclitic, 6(2), pp. 76-86.

Fink. B. (1990) The Seminar of Jacques Lacan. Literature and Psychology, 36(4), pp. 69-76.

Fink, B. (2004) Lacan in 'Translation'. Journal for Lacanian Studies, 2(2), pp. 264-281.

Fink, B. (2014) A Psychoanalytic Ethics of Translation. In Against Understanding: Commentary and Critique in a Lacanian Key. Volume 1. London-New York NY: Routledge, pp. 103-116.

Forrester, J. (1980) Language and the Origins of Psychoanalysis. Basingstoke: Macmillan.

Forrester, J. (1981a) Letter to Jacques-Alain Miller of 7 September 1981. John Forrester Papers, Albert Sloman Library. University of Essex. Box 42.

Forrester, J. (1981b) Letter to Gordon Smith of 7 September 1981. John Forrester Papers, Albert Sloman Library. University of Essex. Box 42.

Forrester, J. (1981c) Letter to Clifford Yorke of 21 September 1981. John Forrester Papers, Albert Sloman Library. University of Essex. Box 42.

Forrester, J. (1981d) Letter to Jacques-Alain Miller of 30 September 1981. John Forrester Papers, Albert Sloman Library. University of Essex. Box 42.

Forrester, J. (1982a) Letter to Serge Leclaire of 30 April 1982. John Forrester Papers, Albert Sloman Library. University of Essex. Box 42.

Forrester, J. (1982b) Letter to Patricia Williams of 10 May 1982. John Forrester Papers, Albert Sloman Library. University of Essex. Box 42.

Forrester, J. (1982c) Letter to Thomas Hayley of 16 August 1982. John Forrester Papers, Albert Sloman Library. University of Essex. Box 42.

Forrester, J. (1982d) The linguistic and the psychotic. The Times Literary Supplement, 1 October, pp. 1079-1080.

Forrester, J. (1982e) Letter to Jonathan Sinclair-Wilson of 22 November 1982. John Forrester Papers, Albert Sloman Library. University of Essex. Box 42. 
Forrester, J. (1983a) Letter to Richard Wollheim of 6 February 1983. John Forrester Papers, Albert Sloman Library. University of Essex. Box 42.

Forrester, J. (1983b) Letter to Linda Healey of 7 September 1983. John Forrester Papers, Albert Sloman Library. University of Essex. Box 42.

Forrester, J. (1984) Letter to Prune Berge of 12 March 1984. John Forrester Papers, Albert Sloman Library. University of Essex. Box 42.

Forrester, J. (1985a) Letter to Jonathan Sinclair-Wilson of 9 April 1985. John Forrester Papers, Albert Sloman Library. University of Essex. Box 42.

Forrester, J. (1985b) Letter to Jacques-Alain Miller of 15 May 1985. John Forrester Papers, Albert Sloman Library. University of Essex. Box 42.

Forrester, J. (1986a) Letter to Jacques-Alain Miller of 2 February 1986. John Forrester Papers, Albert Sloman Library. University of Essex. Box 42.

Forrester, J. (1986b) Letter to Sebastian Gardner of 18 June 1986. John Forrester Papers, Albert Sloman Library. University of Essex. Box 42.

Forrester, J. (1986c) Letter to Joan Copjec of 9 October 1986. John Forrester Papers, Albert Sloman Library. University of Essex. Box 92.

Forrester, J. (1986d) Letter to Joan Copjec of 18 November 1986. John Forrester Papers, Albert Sloman Library. University of Essex. Box 92.

Forrester, J. (1987a) Letter to Jacques-Alain Miller of 25 August 1987. Private archive.

Forrester, J. (1987b) The Seminar of Jacques Lacan: In Place of an Introduction. Book 1: Freud's Papers on Technique. 1953-54. Free Associations, 10, pp. 63-93.

Forrester, J. (1988) The Seminar of Jacques Lacan: In Place of an Introduction. Book 2: The Ego in Freud's Theory and in the Technique of Psychoanalysis. 1954-55. Free Associations, 11, pp. 86-107.

Forrester, J. (1990) The Seductions of Psychoanalysis: Freud, Lacan and Derrida. Cambridge: Cambridge University Press.

Forrester, J. (1990[1979]) Dead on Time: Lacan's Theory of Temporality. In The Seductions of Psychoanalysis: Freud, Lacan and Derrida. Cambridge: Cambridge University Press, pp. 168-218.

Forrester, J. (1990[1987-88]) In Place of an Introduction: The Seminar of Jacques Lacan. Books I and II. In The Seductions of Psychoanalysis: Freud, Lacan and Derrida. Cambridge: Cambridge University Press, pp. 102-140.

Forrester, J. (1991) Letter to Jacques-Alain Miller of 23 March 1991. Private archive.

Forrester, J. (2017[2007]) On Kuhn's Case: Psychoanalysis and the Paradigm. In Thinking in Cases. Cambridge: Polity, pp. 25-64.

Foucault, M. (1967[1961]) Madness and Civilization: A History of Insanity in the Age of Reason. Trans. from the French by R. Howard. London: Tavistock.

Foucault, M. (1972[1969]) The Archaeology of Knowledge. Trans. from the French by A. M. Sheridan Smith. London: Tavistock.

Foucault, M. (2009[2004]) Security, Territory, Population (1977-78) Ed. M. Senellart. Trans. from the French by G. Burchell. Basingstoke: Palgrave Macmillan.

Freud, S. (1961[1925h]) Negation. In The Standard Edition of the Complete Psychological Works of Sigmund Freud, Volume XIX. Ed. and Trans. from the German by J. Strachey. London: The Hogarth Press and the Institute of Psycho-Analysis, pp. 233-239. 
Futter, J. (1986) Letter to John Forrester of 3 December 1986. John Forrester Papers, Albert Sloman Library. University of Essex. Box 42.

Gallagher, C. (1985a) Letter to John Forrester of 21 March 1985. John Forrester Papers, Albert Sloman Library. University of Essex. Box 55.

Gallagher, C. (1985b) Letter to John Forrester of 17 July 1985. John Forrester Papers, Albert Sloman Library. University of Essex. Box 55.

Gallagher, C. (1995) Lacan's Summary of Seminar XI. The Letter: Irish Journal for Lacanian Psychoanalysis, 5, pp. 1-17.

Gerschenfeld, A. (1985) Letter to Jonathan Sinclair-Wilson of 11 October 1985. John Forrester Papers, Albert Sloman Library. University of Essex. Box 42.

Granoff, W. (1975) Filiations. L'avenir du complexe d'EEdipe. Paris: Minuit.

Granoff, W. (1978) La pensée et le féminin. Paris: Minuit.

Granoff, W. (1986) D’un fétiche en forme d'article. In M. Augé (ed.), L'objet en psychanalyse. Le fétiche, le corps, l'enfant, la science. Paris: Denoël, pp. 33-49.

Grigg, R. (1999) Lacan in Translation. Ornicar? Digital, available at http://wapol.org/ornicar/articles/ggg0155.htm, accessed 17 March 2016.

Hart, H. H. (1954) International Journal of Psychoanalysis. XXXIV, 1953: Some Reflections on the Ego. Jacques Lacan. (review), The Psychoanalytic Quarterly, 23, p. 608.

Hayley, T. T. S. (1983) Letter to John Forrester of 31 January 1983. John Forrester Papers, Albert Sloman Library. University of Essex. Box 42.

Healey, L. (1983) Letter to John Forrester of 26 September 1983. John Forrester Papers, Albert Sloman Library. University of Essex. Box 42.

Hegel, G. W. F. (1970[1807]) Phänomenologie des Geistes. In Werke. Vol. 3. Frankfurt am Main: Suhrkamp.

Hegel, G. W. F. (1939) Autonomie et dépendance - Maîtrise et servitude de soi (commenté par Alexandre Kojève) Mesures, 1 (15 janvier), pp. 141-154.

Hopkins, L. (2006) False Self: The Life of Masud Khan. New York NY: Other Press.

Hyppolite, J. (1966[1956]) Appendice I: Commentaire parlé sur la Verneinung de Freud. In J. Lacan, Écrits. Paris: du Seuil, pp. 879-887.

Hyppolite, J. (1988[1956]) Appendix: A Spoken Commentary on Freud's Verneinung, by Jean Hyppolite. In J. Lacan, The Seminar. Book I: Freud's Papers on Technique (1953-54) Ed. J.-A. Miller. Trans. from the French by J. Forrester. Cambridge: Cambridge University Press, pp. 289-297.

Hyppolite, J. (2006[1956]) Appendix I: A Spoken Commentary on Freud’s ‘Verneinung’ by Jean Hyppolite. In J. Lacan, Écrits. Trans. from the French by B. Fink, New York NYLondon: W. W. Norton \& Company, pp. 746-754.

Khan, M. M. R. (1982) Returning to Freud: Clinical Psychoanalysis in the School of Lacan: Selections Edited and Translated by Stuart Schneiderman. New Haven: Yale University Press. 1980. Pp. 265. (book review), The International Journal of Psycho-Analysis, 63(1), pp. 95-98.

Kojève, A. (1969[1947]) Introduction to the Reading of Hegel: Lectures on the Phenomenology of Spirit. Ed. A. Bloom. Trans. and abridged from the French by J. H. Nichols Jr., New York NY: Basic Books. 
Lacan, J. (1953) Some Reflections on the Ego. The International Journal of Psycho-Analysis, 34(1), pp. 11-17.

Lacan, J. (1956[1953]) Fonction et champ de la parole et du langage en psychanalyse. La psychanalyse, 1, pp. 81-166.

Lacan, J. (1957) L’instance de la lettre dans l'inconscient ou la raison depuis Freud. La Psychanalyse, 3, pp. 47-81.

Lacan, J. (1966) Écrits. Paris: du Seuil.

Lacan, J. (1966[1957]) The Insistence of the Letter in the Unconscious. Trans. from the French by J. Miel. Yale French Studies, 36/37, pp. 112-147.

Lacan, J. (1970[1966]) Of Structure as an Inmixing of an Otherness Prerequisite to Any Subject Whatever. In R. Macksey \& E. Donato (eds), The Languages of Criticism and the Sciences of Man. Baltimore MD-London: The Johns Hopkins University Press, pp. 186-200.

Lacan, J. (1972[1956]) Seminar on 'The Purloined Letter'. Trans. from the French by J. Mehlman. Yale French Studies, 48, pp. 38-72.

Lacan, J. (1973) Le Séminaire. Livre XI: Les quatre concepts fondamentaux de la psychanalyse (1964) Texte établi par J.-A. Miller. Paris: du Seuil.

Lacan, J. (1974) Télévision. Paris: du Seuil.

Lacan, J. (1975) Le Séminaire. Livre I: Les écrits techniques de Freud (1953-54) Texte établi par J.-A. Miller. Paris: du Seuil.

Lacan, J. (1977) Écrits: A Selection. Trans. from the French by A. Sheridan. London: Tavistock.

Lacan, J. (1977[1959]) Desire and the Interpretation of Desire in Hamlet. Trans. from the French by J. Hulbert. Yale French Studies, 55/56, pp. 11-52.

Lacan, J. (1977[1970]) Preface. In A. Lemaire, Jacques Lacan. Trans. from the French by D. Macey. London: Routledge and Kegan Paul, pp. vii-xv.

Lacan, J. (1977[1973]) The Four Fundamental Concepts of Psycho-Analysis. Trans. from the French by A. Sheridan. London: The Hogarth Press and the Institute of Psycho-Analysis.

Lacan, J. (1977-78) Le Séminaire XXV: Le moment de conclure. Unpublished.

Lacan. J. (1978) Le Séminaire. Livre II: Le moi dans la théorie de Freud et dans la technique de la psychanalyse (1954-55) Texte établi par J.-A. Miller. Paris: du Seuil.

Lacan, J. (1979[1953]) The Neurotic's Individual Myth. Trans. from the French by M. N. Evans. The Psychoanalytic Quarterly, 48(3), pp. 405-425.

Lacan, J. (1980) Lacan's Letter. Trans. from the French by O. Zentner. Papers of the Freudian School of Melbourne, 1, pp. 2-5.

Lacan, J. (1980[1972]) Ste Anne . . Trans. from the French by D. Green. Semiotext(e), 4(1), pp. 208-218.

Lacan, J. (1980[1976]) A Lacanian Psychosis: Interview by Jacques Lacan. Trans. from the French by S. Schneiderman. In S. Schneiderman (ed.), Returning to Freud: Clinical Psychoanalysis in the School of Lacan. New Haven CT-London: Yale University Press, pp. 19-41.

Lacan, J. (1981a) The Seminar, Paris, June $10^{\text {th }} 1980$. Trans. from the French by O. Zentner. Papers of the Freudian School of Melbourne, 2, pp. 97-101.

Lacan, J. (1981b) The Seminar, Caracas, July $12^{\text {th }} 1980$. Trans. from the French by O. Zentner. Papers of the Freudian School of Melbourne, 2, pp. 103-106. 
Lacan, J. (1981c) Le Séminaire. Livre III: Les psychoses (1955-56) Texte établi par J.-A. Miller. Paris: du Seuil.

Lacan, J. (1986) Le Séminaire. Livre VII: L'éthique de la psychanalyse (1959-60) Texte établi par J.-A. Miller. Paris: du Seuil.

Lacan, J. (1987[1974]) Television. Trans. D. Hollier, R. Krauss \& A. Michelson. October, 40, pp. 5-50.

Lacan, J. (1988[1945]) Logical Time and the Assertion of Anticipated Certainty: A New Sophism. Trans. from the French by M. Silver \& B. Fink. Newsletter of the Freudian Field, 2(2), pp. 4-22.

Lacan, J. (1988[1975]) The Seminar. Book I: Freud's Papers on Technique (1953-54) Ed. J.A. Miller. Trans. from the French by J. Forrester. Cambridge: Cambridge University Press.

Lacan, J. (1988[1978]) The Seminar. Book II: The Ego in Freud's Theory and in the Technique of Psychoanalysis (1954-55) Ed. J.-A. Miller. Trans. from the French by S. Tomaselli, with notes by J. Forrester. Cambridge: Cambridge University Press.

Lacan, J. (1990[1974]) Television. Trans. D. Hollier, R. Krauss \& A. Michelson. In J. Copjec (ed.) Television/A Challenge to the Psychoanalytic Establishment. New York NY-London: W. W. Norton \& Company, pp. 1-46.

Lacan, J. (1992[1986]) The Seminar. Book VII: The Ethics of Psychoanalysis (1959-60) Ed. J.A. Miller. Trans. from the French by D. Porter. New York NY-London: W. W. Norton \& Company.

Lacan, J. (1993[1981]) The Seminar. Book III: The Psychoses (1955-56) Ed. J.-A. Miller. Trans. from the French by R. Grigg. New York NY-London: W. W. Norton \& Company.

Lacan, J. (1994[1973]) The Four Fundamental Concepts of Psycho-Analysis. Trans. from the French by A. Sheridan, with a new introduction by D. Macey. Harmondsworth: Penguin.

Lacan, J. (1998[1975]) The Seminar. Book XX: On Feminine Sexuality, the Limits of Love and Knowledge (Encore) (1972-73) Ed. J.-A. Miller, Trans. from the French by B. Fink, New York NY-London, W. W. Norton \& Company.

Lacan, J. (2001a[1938]) Les complexes familiaux dans la formation de l'individu. Essai d'analyse d'une fonction en psychologie. In Autres écrits. Paris: du Seuil, pp. 23-84.

Lacan, J. (2001b[1946]) Le nombre treize et la forme logique de la suspicion. In Autres écrits. Paris: du Seuil, pp. 85-99.

Lacan, J. (2005) Le Séminaire. Livre XXIII: Le sinthome (1975-76) Texte établi par J.-A. Miller. Paris: du Seuil.

Lacan, J. (2006[1945]) Logical Time and the Assertion of Anticipated Certainty: A New Sophism. In Écrits. Trans. from the French by B. Fink. New York NY-London: W. W. Norton \& Company, pp. 161-175.

Lacan, J. (2007[1991]) The Seminar. Book XVII: The Other Side of Psychoanalysis (1969-70) Ed. J.-A. Miller. Trans. from the French by R. Grigg. New York NY-London: W. W. Norton \& Company.

Lacan, J. (2012[1965]) Postface to Seminar XI. Trans. from the French by A. Price. HurlyBurly: The International Lacanian Journal of Psychoanalysis, 7, pp. 17-21.

Lacan, J. (2013) Lituraterre. Continental Philosophy Review, 46(2), pp. 327-334.

Lacan, J. (2016[2005]) The Seminar. Book XXIII: The Sinthome (1975-76) Ed. J.-A. Miller, Trans. from the French by A. R. Price, Cambridge: Polity. 
Lacan, J. and Granoff, W. (1956) Fetishism: The Symbolic, the Imaginary and the Real. In S. Lorand (ed.), Perversions: Psychodynamics and Therapy. New York NY: Gramercy Books, pp. 265-276.

Laing, R. D. (1960) The Divided Self: A Study of Sanity and Madness. London: Tavistock.

Laing, R. D. (1961) Self and Others. London: Tavistock.

Lays, F. (1985) Letter to John Forrester of 10 July 1985. John Forrester Papers, Albert Sloman Library. University of Essex. Box 42.

Leclaire, S. (1968) Psychanalyser. Essai sur l'ordre de l'inconscient et la pratique de la lettre. Paris: du Seuil.

Leclaire, S. (1982) Letter to John Forrester of 11 May 1982. John Forrester Papers, Albert Sloman Library. University of Essex. Box 42.

Leclaire, S. (1998[1968]) Psychoanalyzing: On the Order of the Unconscious and the Practice of the Letter. Trans. from the French by P. Kamuf. Stanford CA-London: Stanford University Press.

Lemaire, A. (1977[1970]) Jacques Lacan. Trans. from the French by D. Macey. London: Routledge and Kegan Paul.

Macey, D. (1989) Lacan: The Seminar. Radical Philosophy, 51, pp. 46-47.

Michelson, A., Krauss, R. \& Copjec, J. (1986) Letter to John Forrester of 11 December 1986. John Forrester Papers, Albert Sloman Library. University of Essex. Box 92.

Miel, J. (1966) Jacques Lacan and the Structure of the Unconscious. Yale French Studies, 36/37, pp. 104-111.

Miller, J. (1981) Letter to John Forrester of 17 October 1981. John Forrester Papers, Albert Sloman Library. University of Essex. Box 42.

Miller, J.-A. (Ed.) (1977) L'excommunication. La communauté psychanalytique en France 2. Paris: Navarin.

Miller, J.-A. (1982a) Letter to John Forrester of 31 May 1982. John Forrester Papers, Albert Sloman Library. University of Essex. Box 42.

Miller, J.-A. (1982b) Letter to John Forrester of 13 September 1982. John Forrester Papers, Albert Sloman Library. University of Essex. Box 42.

Miller, J.-A. (1982c) Letter to John Forrester of 28 October 1982. John Forrester Papers, Albert Sloman Library. University of Essex. Box 42.

Miller, J.-A. (1985a) Letter to John Forrester of 19 February 1985. John Forrester Papers, Albert Sloman Library. University of Essex. Box 42.

Miller, J.-A. (1985b) Letter to John Forrester of 20 September 1985. John Forrester Papers, Albert Sloman Library. University of Essex. Box 42.

Miller, J.-A. (1985c) Letter to John Forrester of 26 September 1985. John Forrester Papers, Albert Sloman Library. University of Essex. Box 42.

Miller, J.-A. (1985d) Entretien sur Le Séminaire avec François Ansermet. Paris: Navarin.

Miller, J.-A. (1986a) Letter to John Forrester of 3 March 1986. John Forrester Papers, Albert Sloman Library. University of Essex. Box 42.

Miller, J.-A. (1986b) Letter to John Forrester of 14 April 1986. John Forrester Papers, Albert Sloman Library. University of Essex. Box 42.

Miller, J.-A. (1986c) Letter to John Forrester of 20 June 1986. John Forrester Papers, Albert Sloman Library. University of Essex. Box 42. 
Miller, J.-A. (1986d) Letter to John Forrester of 10 September 1986. John Forrester Papers, Albert Sloman Library. University of Essex. Box 92.

Miller, J.-A. (2006a) Aide au lecteur. In J. Lacan, Le Séminaire. Livre XVI: D’un Autre à l'autre (1968-69) Texte établi par J.-A. Miller. Paris: du Seuil, pp. 415-420.

Miller, J.-A. (2006b) Quelques références de Lacan à Lacan, et à d'autres. In J. Lacan, Le Séminaire. Livre XVIII: D’un discours qui ne serait pas du semblant (1971) Texte établi par J.-A. Miller. Paris: du Seuil, pp. 181-183.

Miller, J.-A. (2011) Bibliothèque du Séminaire XIX. In J. Lacan, Le Séminaire. Livre XIX: ... ou pire (1971-72) Texte établi par J.-A. Miller. Paris: du Seuil, pp. 245-254.

Miller, J.-A. (2013) Marginalia du Séminaire du désir. Quelques références utiles, avec des associations qui me sont venues. In J. Lacan, Le Séminaire. Livre VI: Le désir et son interprétation (1958-59) Texte établi par J.-A. Miller. Paris: du Seuil, pp. 575-610.

Miller, J.-A. (2016[2005]) A Note Threaded Stitch by Stitch. In J. Lacan, The Seminar. Book XXIII: The Sinthome (1975-76) Ed. J.-A. Miller, Trans. from the French by A. R. Price, Cambridge: Polity, pp. 176-221.

Milner, J.-C. (1978) L'amour de la langue. Paris: du Seuil.

Milner, J.-C. (1990[1978]) For the Love of Language. Trans. from the French by A. Banfield. Basingstoke: Macmillan.

Mitchell, J. and Rose, J. (eds) (1982) Feminine Sexuality: Jacques Lacan and the école freudienne. Trans. from the French J. Rose. New York NY-London: W. W. Norton \& Company.

Nobus, D. (2003) Transference in Writing: Some Notes on 'Fetishism: The Symbolic, the Imaginary and the Real'. Journal for Lacanian Studies, 1(2), pp. 309-316.

Nobus, D. (2013) Annotations to Lituraterre. Continental Philosophy Review, 46(2), pp. 335347.

Roudinesco, E. (1990[1986]) Jacques Lacan \& Co.: A History of Psychoanalysis in France 1925-1985. Trans. from the French by J. Mehlman. London: Free Association Books.

Roudinesco, E. (1997[1994]) Jacques Lacan. Trans. from the French by B. Bray. New York NY-London: Columbia University Press.

Safouan, M. (1974) Études sur l'Edipe. Introduction à une théorie du sujet. Paris: du Seuil.

Schneiderman, S. (ed.) (1980) Returning to Freud: Clinical Psychoanalysis in the School of Lacan. New Haven CT-London: Yale University Press.

Sibony, D. (2007[1993]) Le peuple 'psy'. Paris: du Seuil.

Sinclair-Wilson, J. (1982) Letter to John Forrester of 23 April 1982. John Forrester Papers, Albert Sloman Library. University of Essex. Box 42.

Sinclair-Wilson, J. (1983) Letter to John Forrester of 20 April 1983. John Forrester Papers, Albert Sloman Library. University of Essex. Box 42.

Sinclair-Wilson, J. (1984) Letter to John Forrester of 16 February 1984. John Forrester Papers, Albert Sloman Library. University of Essex. Box 42.

Sinclair-Wilson, J. (1985) Letter to John Forrester of 4 March 1985. John Forrester Papers, Albert Sloman Library. University of Essex. Box 42.

Smith, G. (1981) Letter of 2 October 1981 to John Forrester. John Forrester Papers, Albert Sloman Library. University of Essex. Box 42.

Turkle, S. (1989) Why Are You Here?. London Review of Books, 11(1), pp. 3-5. 
Wilden, A. G. (1966) Jacques Lacan: A Partial Bibliography. Yale French Studies, 36/37, pp. 263-268.

Wilden, A. G. (1968a) Jacques Lacan and the Language of the Self: The Function of Language in Psychoanalysis. PhD dissertation. The Johns Hopkins University.

Wilden, A. (1968b) The Language of the Self: The Function of Language in Psychoanalysis. Baltimore MD-London: The Johns Hopkins University Press.

Willemen, P. (1982) Letter to Jonathan Sinclair-Wilson of 22 April 1982. John Forrester Papers, Albert Sloman Library. University of Essex. Box 42.

Wollheim, R. \& Hopkins, J. (eds) (1982) Philosophical Essays on Freud. Cambridge: Cambridge University Press.

\begin{abstract}
Drawing on archival sources and personal recollections, this essay reconstructs the troubled history of the first robust attempt at making the works of the French psychoanalyst Jacques Lacan newly available to an anglophone readership, after his death in 1981. It details how the project was initiated by John Forrester as part of a large-scale initiative to generate translations of both Lacan's own texts and seminars, and various books written in the Lacanian tradition. If, almost seven years after it was conceived, Forrester's project only resulted in the publication of English translations of Lacan's first two public seminars, the essay demonstrates that this was not owing to disagreements over the quality of Forrester's work, but because of two consecutive sources of resistance. External resistance from publishers first led to the initial project being reduced to the translation of two seminars, whereas internal resistance from Lacan's son-in-law Jacques-Alain Miller to Forrester's vision of presenting the seminars with a full scholarly apparatus subsequently brought about delays in its execution.
\end{abstract}

Keywords: Jacques Lacan, John Forrester, Jacques-Alain Miller, Lacanian psychoanalysis, Translation, Seminar 1, Seminar 2 